\title{
Aggregative adherent strains of Corynebacterium pseudodiphtheriticum enter and survive within HEp-2 epithelial cells
}

\author{
Monica Cristina de Souza1, Louisy Sanches dos Santos ${ }^{1}$, Débora Leandro Rama Gomes ${ }^{1,2}$, \\ Priscila Soares Sabbadini ${ }^{1,3}$, Cinta Silva dos Santos' ${ }^{1}$, Thereza Christina Ferreira Camello \\ Lídia Maria Buarque Oliveira Asad ${ }^{4}$, Ana Claúdia de Paula Rosa ${ }^{1}$, Prescilla Emy Nagao ${ }^{5}$, \\ Raphael Hirata Júnior ${ }^{1}$, Ana Luiza de Mattos Guaraldi ${ }^{1 /+}$
}

\author{
${ }^{1}$ Laboratório de Difteria e Corinebacterias de Importância Clínica, Faculdade de Ciências Médicas ${ }^{4}$ Departamento de Biofísica e Biometria \\ ${ }^{5}$ Departamento de Biologia Celular, Instituto de Biologia Roberto Alcântara Gomes, Universidade do Estado do Rio de Janeiro, \\ Rio de Janeiro, RJ, Brasil 'Faculdade de Farmácia, Instituto Federal de Educação, Ciência e Tecnologia do Rio de Janeiro, \\ Rio de Janeiro, RJ, Brasil ${ }^{3}$ Laboratório de Doenças Bacterianas Respiratórias e Sistêmicas, \\ Centro Universitário do Maranhão, São Luís, MA, Brasil
}

Corynebacterium pseudodiphtheriticum is a well-known human pathogen that mainly causes respiratory disease and is associated with high mortality in compromised hosts. Little is known about the virulence factors and pathogenesis of C. pseudodiphtheriticum. In this study, cultured human epithelial (HEp-2) cells were used to analyse the adherence pattern, internalisation and intracellular survival of the ATCC 10700 type strain and two additional clinical isolates. These microorganisms exhibited an aggregative adherence-like pattern to HEp-2 cells characterised by clumps of bacteria with a "stacked-brick" appearance. The differences in the ability of these microorganisms to invade and survive within HEp-2 cells and replicate in the extracellular environment up to 24 h post infection were evaluated. The fluorescent actin staining test demonstrated that actin polymerisation is involved in the internalisation of the C. pseudodiphtheriticum strains. The depolymerisation of microfilaments by cytochalasin E significantly reduced the internalisation of C. pseudodiphtheriticum by HEp-2 cells. Bacterial internalisation and cytoskeletal rearrangement seemed to be partially triggered by the activation of tyrosine kinase activity. Although C. pseudodiphtheriticum strains did not demonstrate an ability to replicate intracellularly, HEp-2 cells were unable to fully clear the pathogen within $24 \mathrm{~h}$. These characteristics may explain how some C. pseudodiphtheriticum strains cause severe infection in human patients.

Key words: aggregative-like adherence pattern - Corynebacterium pseudodiphtheriticum -

HEp-2 cells - intracellular survival - persistence

Currently, more than half of all of the infectious diseases that affect mildly immunocompromised patients involve bacterial species that are commonly encountered in the environment or are found among the body's normal flora. Opportunistic pathogens, including Corynebacterium pseudodiphtheriticum, are frequently resistant to antimicrobial agents and there is no effective vaccine against this microbe. C. pseudodiphtheriticum has been reported to cause human disease in both immunocompromised and immunocompetent individuals, despite the fact that it is commonly found as a harmless commensal organism on the skin and in the upper respiratory tract (Ahmed et al. 1995, Burke et al. 1997, von Graevenitz et al. 1998, Camello et al. 2009, Martins et al. 2009, Bittar et al. 2010, Olender \& Niemcewicz 2010). Infections caused by C. pseudodiphtheriticum include endocarditis (Morris \& Guild 1991), bacteraemia

Financial support: CNPq, FAPERJ, SR-2/UERJ, PNPD (CNPq/ CAPES), PAPD (FAPERJ/CAPES) and PRONEX/MCT

+ Corresponding author: guaraldi@uerj.br

Received 7 September 2011

Accepted 15 February 2012
(Das et al. 2003), pneumonia (Roig et al. 1993, Chiner et al. 1999, Martaresche et al. 1999, Chudnicka et al. 2003, Morinaga et al. 2010), tracheobronchitis (Craig et al. 1991), necrotising tracheitis (Colt et al. 1991), exudative pharyngitis (Izurieta et al. 1997) and rhinosinusitis (Voiriot et al. 1986), in addition to osteitis (Roux et al. 2004), arthritis (Kemp et al. 2005), suppurative lymphadenitis (LaRocco et al. 1987), conjunctivitis (Li \& Lal 2000) and skin (Cantarelli et al. 2008) and urinary tract infections (Nathan et al. 1982).

Opportunistic pathogens may have an array of virulence factors that facilitate their attachment to host cells and enable tissue invasion. Recent advances in the understanding of the molecular biology of these organisms have shed considerable light on the ability of these pathogens to survive within host tissues and confer resistance to clearance by host immune mechanisms and antimicrobial agents (Odeh \& Quinn 2000). Therefore, a better understanding of the biology and recognition of the virulent potential of $C$. pseudodiphtheriticum strains may help to effectively prevent the infections caused by them. To date, only one study has described the interaction of $C$. pseudodiphtheriticum with eukaryotic cells (Yanagawa \& Honda 1976). The authors of that report showed that the C. pseudodiphtheriticum ATCC 10700 strain possessed a large number of pili, ranging from 
dozens to more than a hundred, in $91-100 \%$ of the bacterial cells. However, the microorganism did not show the ability to agglutinate sheep erythrocytes, suggesting that some C. pseudodiphtheriticum strains exhibit a haemagglutination (HA)-negative phenotype, as previously observed for some strains of diphtheria bacilli (MattosGuaraldi \& Formiga 1991). For some human pathogens, the (HA)-positive phenotype was reported to be more virulent than the non-haemadherent phenotype (Kang et al. 2002). Additional studies are necessary to investigate whether C. pseudodiphtheriticum strains that have the (HA)-positive phenotype exist and, if so, to what extent they are involved in human infections.

In this study, we investigated the adherence pattern, invasion, intracellular survival and persistence of $C$. pseudodiphtheriticum within human epithelial cells.

\section{MATERIALS AND METHODS}

Bacterial strains and culture conditions - The $C$. pseudodiphtheriticum ATCC 10700 type strain, isolated from exudative pharyngitis (Izurieta et al. 1997) and two clinical isolates previously obtained from patients $\mathrm{Ca}-$ mello et al. 2009, Martins et al. 2009) that were treated at a teaching hospital in the metropolitan area of Rio de Janeiro, Brazil were used in these experiments. The clinical strains included the HTR1503 strain, which was isolated from the bronchoalveolar lavage (BAL) of a patient with pneumonia, and the $\mathrm{HHC1507}$ strain, which was isolated from a blood sample of a patient with bacteraemia. The microorganism identification originally conducted using conventional biochemical tests (Funke \& Bernard 2007, Camello et al. 2009) was reconfirmed by the use of the API-Coryne System (bioMérieux, Lyon, France), according to the manufacturer's instructions, using several profiles: 1001004, 3001004 and 3001004 (all probabilities $>90 \%$ ) (Almuzara et al. 2006). Stock cultures were maintained in $10 \%$ skim milk containing $25 \%$ glycerol at $-80^{\circ} \mathrm{C}$.

All experiments were conducted with microorganisms grown in trypticase soy broth for $48 \mathrm{~h}$ at $37^{\circ} \mathrm{C}$ and washed twice in phosphate-buffered saline (PBS) $(0.01$ M; pH 7.2) (Hirata Jr et al. 2002).

Haemagglutination (HA) - HA assays were performed with $0.5 \%$ suspensions of human $B$ erythrocytes, as previously described for Corynebacterium diphtheriae. The CDC E-8392 and TR241 strains were used as positive and negative controls, respectively (Mattos-Guaraldi et al. 1991).

Qualitative and quantitative human epithelial (HEp-2) adherence, invasion and persistence assays HEp-2 cells, derived from a human epidermoid larynx carcinoma, were grown in Eagle's minimum essential medium (MEM) (Sigma Chemical Co, MO, USA) supplemented with $5 \%$ foetal calf serum (FCS) (Gibco BRL, NY, USA), $50 \mu \mathrm{g} \mathrm{mL}^{-1}$ gentamicin, $2.5 \mu \mathrm{g} \mathrm{mL}^{-1}$ amphotericin $\mathrm{B}$ and $0.5 \% \mathrm{~L}$-glutamine at $37^{\circ} \mathrm{C}$, in a $5 \%$ $\mathrm{CO}_{2}$ atmosphere.

Adherence assays were performed with semi-confluent HEp-2 monolayers grown on circular cover slips (13 $\mathrm{mm}$ diameter). At $3 \mathrm{~h}$ post-infection, Giemsa-stained cover slips were examined by bright field microscopy. Microorganisms were evaluated for their ability to demonstrate the following adherence patterns: localised adherence (LA), characterised by small clusters of bacteria resembling microcolonies, diffuse adherence (DA), characterised by bacteria randomly distributed over the surfaces of the HEp-2 cells, or aggregative adherence (AA), characterised by clumps of bacteria with a "stacked-brick" appearance. C. diphtheriae CDC E-8392, TR241 and HC01 strains were used as controls for DA, LA and AA-like adherence patterns, respectively (Hirata Jr et al. 2004, 2008).

Bacterial viable counts were performed using monolayers of HEp-2 cells grown to approximately 95\% confluence and infected with C. pseudodiphtheriticum $\left[10^{6}-10^{7}\right.$ colony-forming unit (CFU) $\left.\mathrm{mL}^{-1}\right]$ suspended in MEM [multiplicity of infection (MOI) of 10]. After incubation periods of $0.5 \mathrm{~h}, 1 \mathrm{~h}, 3 \mathrm{~h}, 6 \mathrm{~h}$ and $24 \mathrm{~h}$, infected HEp-2 cells were washed six times, lysed with $0.1 \%$ Triton X-100 in PBS and diluted and plated onto Columbia agar base (Hirata Jr et al. 2002, 2004).

To determine the intracellular viable bacteria (IC) counts, monolayers were washed six times with PBS and treated with $150 \mu \mathrm{g} \mathrm{mL}^{-1}$ gentamicin sulphate for $1 \mathrm{~h}$. The number of IC was determined after lysis of the monolayers with $250 \mu \mathrm{L}$ of $0.1 \%$ Triton X-100 in PBS. For each incubation period, the percentage of intracellular bacteria was deduced from the number of HEp-2 cell-associated bacteria. Index values of the IC related to bacteria associated with HEp-2 cell monolayers were also determined (Hirata Jr et al. 2002, 2004, Moreira et al. 2003). The bacterial counts (CFU) in supernatants and HEp-2 monolayer lysates were determined at each incubation period. The percentage of cell-associated bacteria $(\mathrm{EC}+\mathrm{IC})$ at each incubation period was calculated as follows: lysate CFU $\times$ (lysate CFU + supernatant CFU) $)^{-1} \times 100$ (Moreira et al. 2003).

To evaluate bacterial persistence, viable bacteria were recovered from the lysates of monolayers maintained in the presence of gentamicin for $24 \mathrm{~h}$ (T24P). Briefly, the monolayers were washed six times with PBS at $3 \mathrm{~h}$ post-infection and subsequently treated with 150 $\mu \mathrm{g} \mathrm{mL}^{-1}$ gentamicin sulphate for $24 \mathrm{~h}$. The persistence of intracellular bacteria was determined by viable counts $\left(\mathrm{CFU} \mathrm{mL} \mathrm{mL}^{-1}\right)$ conducted after the monolayers were lysed with $250 \mu \mathrm{L}$ of $0.1 \%$ Triton X-100 in PBS at $24 \mathrm{~h}$ postinfection (Döpfer et al. 2001).

Fluorescent actin staining (FAS) test - Semi-confluent HEp-2 monolayers were infected with the bacterial strains. After $3 \mathrm{~h}$ of incubation, infected cells were rinsed six times with PBS, fixed for 15 min with $3 \%$ formaldehyde and then treated with $0.1 \%$ Triton X-100 in PBS for $5 \mathrm{~min}$. Monolayers were washed three times with PBS and treated with $5 \mu \mathrm{g} \mathrm{mL}^{-1}$ fluorescein-conjugated phalloidin (Sigma) for $30 \mathrm{~min}$. FAS test results were considered positive when foci of intense fluorescence corresponded to areas of bacterial adhesion observed under phase-contrast microscopy (Hirata Jr et al. 2004). The C. diphtheriae CDC E-8392 strain was used as a positive control (data not shown).

Treatment of HEp-2 cells with cytochalasin $E$ and genistein - HEp-2 monolayers were pre-treated with $5 \mu \mathrm{M}$ cytochalasin $\mathrm{E}$ and $100 \mu \mathrm{M}$ genistein (both pur- 
chased from Sigma) in MEM for $30 \mathrm{~min}$ and washed twice before bacterial infection. The percentages of cell-associated and IC were determined as described above (Hirata Jr et al. 2004).

Statistical analysis - Each experiment was carried out in triplicate and repeated three times. Statistical analysis was performed using Tukey's test in GraphPad Prism software to compare the means of the experimental groups; $\mathrm{p}<0.05$ was considered statistically significant.

\section{RESULTS}

$H A$ - None of the microorganisms we tested were able to agglutinate human erythrocytes, including the fimbriated ATCC 10700 type strain (data not shown).

Adherence, entry and survival of $C$. pseudodiphtheriticum strains in HEp-2 cells - The microscopic examination of HEp-2 epithelial cells infected with C. pseudodiphtheriticum revealed an AA-like adherence pattern characterised by clumps of bacteria with a "stacked-brick" appearance (3 h), as illustrated in Fig. 1. Microorganisms were also attached to the surfaces of the cultured epithelial cells at focal points and to exposed areas of the glass slide around the HEp-2 cells. HEp-2 cells that were infected with C. pseudodiphtheriticum showed large cytoplasmic vacuoles.

The results of the quantitative cell-associated bacteria $(\mathrm{EC}+\mathrm{IC})$ and IC tests at different incubation times are shown in Table I. C. pseudodiphtheriticum strains were able to adhere to and survive within HEp-2 cells at different levels at the specified periods of incubation. Viable cell-associated bacteria were detected at $30 \mathrm{~min}$ post-infection. The highest percentages of associated bacteria were observed at $6 \mathrm{~h}$ post-infection. Viable associated bacteria were detected at different levels at $24 \mathrm{~h}$ post-infection for the ATCC 10700/pharyngitis (15.13\%) and HTR1503/pneumonia (51.90\%) strains, except for

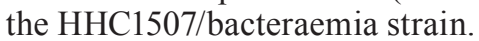

Viable internalised bacteria were initially detected at $3 \mathrm{~h}$ post-infection of the monolayers, regardless of the origin of the C. pseudodiphtheriticum strain. The highest percentages of viable intracellular bacteria deduced from HEp-2 cell-associated bacteria were observed at 6 h post-infection for the HHC1507/bacteraemia (3.43\%) and ATCC 10700/pharyngitis (3.23\%) strains. The ATCC 10700/pharyngitis strain showed an average ratio of viable intracellular bacteria to bacteria associated with HEp-2 cell monolayers of 1:10, while the HHC1507/ bacteraemia and HTR1503/pneumonia strains exhibited ratios of $1: 38$ and $1: 54$, respectively.

Although all strains tested were able to adhere to and survive within HEp-2 cells until $6 \mathrm{~h}$ post-infection, the ATCC 10700/pharyngitis type strain exhibited greater survival (44.82\%) within HEp-2 cells at $24 \mathrm{~h}$ post infection than did the HTR1503 (pneumonia) strain (0.38\%) (Table I). For the HHC1507 strain (bacteraemia), viable bacterial cells were only observed in the supernatant of infected HEp-2 cells at $24 \mathrm{~h}$ post-infection (Table II).

Bacterial persistence following a longer period of infection $(24 h)$ - The results of the experiments on the intracellular survival and persistence of $C$. pseudodiphthe-
A

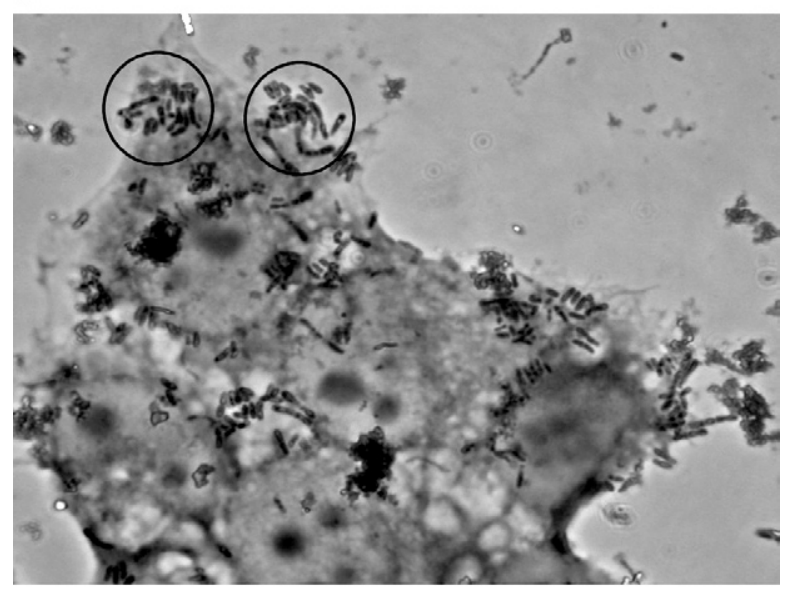

B

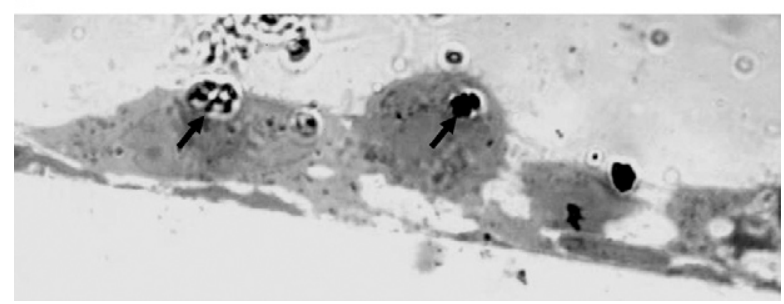

Fig. 1: light micrographs illustrating the aggregative (AA)-like adherence pattern to human epithelial (HEp-2) cells (3 h) of Corynebacterium pseudodiphtheriticum (HHC1507 strain). AA-like adherence pattern was characterized by clumps of bacteria with a "stacked-brick" appearance (circles) (A); bacterial aggregates of ATCC 10700 strain when adherent to and internalized within loose vacuoles by HEp-2 cells (6 h) (B). Magnification: 1,000X.

riticum strains at $24 \mathrm{~h}$ post-infection are shown in Table II. C. pseudodiphtheriticum strains were able to survive in the presence of HEp-2 cells at different levels until $24 \mathrm{~h}$ post-infection. Bacterial growth in the extracellular environment after this long period of incubation (24 h) was observed only for the ATCC 10700/pharyngitis type strain. The intracellular persistence of bacteria at $24 \mathrm{~h}$ post infection was observed for both the C. pseudodiphtheriticum ATCC 10700/pharyngitis type strain and the HTR1503/pneumonia strains ( $p>0.05$ ), but not for the HHC1507/bacteraemia strain. The clinical isolates were unable to replicate intracellularly under the experimental conditions that were used.

The evaluation of the cytoskeletal rearrangements accompanying the adherence and entry of C. pseudodiphtheriticum into HEp-2 cells - As shown by the FAS test, $C$. pseudodiphtheriticum was able to trigger actin polymerisation in HEp-2 cells (Fig. 2). The accumulation of polymerised actin was observed directly beneath the adherent bacteria.

The results exhibited in Fig. 3 show that the internalisation of the C. pseudodiphtheriticum HHC1507/ bacteraemia and HTR1503/pneumonia strains was completely inhibited by cytochalasin E. The adhesion of the HHC1507/bacteraemia strain to HEp-2 cells was also 
TABLE I

Corynebacterium pseudodiphtheriticum viable cells associated to and internalized by human epithelial (HEp-2) epithelial cells at different periods of incubation

\begin{tabular}{|c|c|c|c|c|c|c|}
\hline \multirow[b]{3}{*}{$\begin{array}{l}\text { Time } \\
\text { (h) }\end{array}$} & \multicolumn{6}{|c|}{ Viable bacteria } \\
\hline & \multicolumn{2}{|c|}{$\begin{array}{c}\text { ATCC 10700/ } \\
\text { exudative pharyngitis }\end{array}$} & \multicolumn{2}{|c|}{$\begin{array}{l}\text { HTR1503/ } \\
\text { pneumonia }\end{array}$} & \multicolumn{2}{|c|}{$\begin{array}{c}\text { HHC1507/ } \\
\text { bacteraemia }\end{array}$} \\
\hline & $\begin{array}{c}\mathrm{EC}+\mathrm{IC} \\
(\%)\end{array}$ & $\begin{array}{l}\mathrm{IC} \\
(\%)\end{array}$ & $\begin{array}{c}\mathrm{EC}+\mathrm{IC} \\
(\%)\end{array}$ & $\begin{array}{l}\mathrm{IC} \\
(\%)\end{array}$ & $\begin{array}{c}\mathrm{EC}+\mathrm{IC} \\
(\%)\end{array}$ & $\begin{array}{l}\mathrm{IC} \\
(\%)\end{array}$ \\
\hline T0.5S & $10.51^{a}$ & 0 & $31.16^{d}$ & 0 & 4.41 & 0 \\
\hline T1S & 43.30 & 0 & 16.36 & 0 & $43.92^{f}$ & 0 \\
\hline T3S & $56^{b}$ & $3.23^{c}$ & $31.31^{d}$ & 0.65 & $44.36^{f}$ & 0.36 \\
\hline T6S & $53.70^{b}$ & $3.23^{c}$ & $51.15^{e}$ & 1.70 & 48.83 & 3.43 \\
\hline $\mathrm{T} 24 \mathrm{~S}$ & $15.13^{a}$ & 44.82 & $51.90^{e}$ & 0.38 & 0 & 0 \\
\hline
\end{tabular}

$a-f$ : results of comparative analysis presenting $\mathrm{p}>0.05$. EC + IC: extracellular + intracellular (viable bacteria associated to HEp-2 cells); IC: viable associated bacteria found in cell lysates obtained from monolayers previously treated with gentamicin (1 h). Means of three experiments and repeated three times. $\mathrm{p}<0.05$ considered statistically significant.

TABLE II

Survival (T24S) and persistence (T24P) of Corynebacterium pseudodiphtheriticum strains at $24 \mathrm{~h}$ post infection of human epithelial (HEp-2) epithelial cells ${ }^{a}$

\begin{tabular}{|c|c|c|c|c|c|c|}
\hline & \multicolumn{6}{|c|}{ Viable bacteria (colony-forming unit $\mathrm{mL}^{-1}$ ) } \\
\hline & \multicolumn{2}{|c|}{$\begin{array}{c}\text { ATCC } 10700 / \\
\text { exudative pharyngitis }\end{array}$} & \multicolumn{2}{|c|}{$\begin{array}{l}\text { HTR1503/ } \\
\text { pneumonia }\end{array}$} & \multicolumn{2}{|c|}{$\begin{array}{l}\text { HHC1507/ } \\
\text { bacteremia }\end{array}$} \\
\hline & SN & IC & SN & $\mathrm{IC}$ & $\mathrm{SN}$ & $\mathrm{IC}$ \\
\hline T0 & $8.7 \times 10^{6}$ & - & $6.7 \times 10^{6}$ & - & $16 \times 10^{6}$ & - \\
\hline $\mathrm{T} 24 \mathrm{~S}$ & $1.27 \times 10^{7}$ & $1.07 \times 10^{7 b}$ & $3.0 \times 10^{6}$ & $1 \times 10^{6 c}$ & $9 \times 10^{5}$ & 0 \\
\hline $\mathrm{T} 24 \mathrm{P}$ & 0 & $1 \times 10^{4 b}$ & 0 & $1 \times 10^{4 b}$ & 0 & 0 \\
\hline
\end{tabular}

$a$ : bacterial inoculums of $\sim 8 \times 10^{6}$ bacteria; $b, c$ : results of comparative analysis considering $\mathrm{p}>0.05$; IC: viable bacteria recovered at $24 \mathrm{~h}$ post-infection from lysates of monolayers previously treated $(1 \mathrm{~h})$ with gentamicin (T24S) and maintained in the presence gentamicin (T24P); SN: viable bacteria recovered from the supernatants of infected monolayers. Means of three experiments and repeated three time. $\mathrm{p}<0.05$ considered statistically significant.

completely inhibited by blocking actin polymerisation. For the HTR1503/pneumonia strain, the inhibition of internalisation led to a greater deposition of bacteria on the surfaces of cytochalasin E treated cells. These data indicate that actin-dependent mechanisms are involved in the adherence and internalisation of the HHC1507 strain. In contrast, distinct mechanisms could account for the adherence and internalisation of the HTR 1503 strain. An actin-dependent mechanism seemed to be involved in the internalisation, but not the adherence, of the invasive HTR1503 strain.

For the ATCC 10700-type strain, cytochalasin did not completely inhibit bacterial adherence or invasion, suggesting that actin-independent mechanisms contribute both processes.
To investigate whether the adherence and invasion processes involved actin polymerisation via a phosphotyrosine-signalling cascade, the bacterial interaction with HEp-2 cells was evaluated in the presence of genistein, a tyrosine kinase inhibitor. The data indicate that the $C$. pseudodiphtheriticum adherence and invasion processes involve actin polymerisation via a phosphotyrosine-signalling cascade in different ways.

The adherence processes of the ATCC 10700 and HHC1507 strains involved actin polymerisation via a phosphotyrosine-signalling cascade at different levels $(p<0.05)$. The inhibitory effect of genistein on internalisation was significant for ATCC 10700 ( $\mathrm{p}<0.001)$ and HTR1503 ( $<<0.05)$ strains. Conversely, the inhibition of the phosphotyrosine-signalling cascade led to a 
A

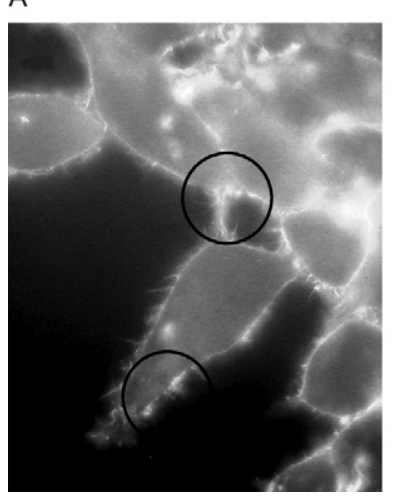

B

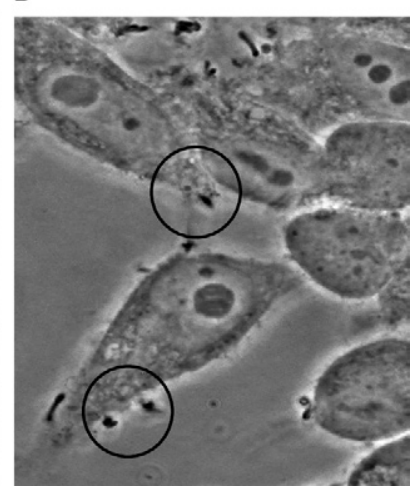

Fig. 2: fluorescence (A) and phase-contrast microscopy (B) showing positive fluorescent actin staining (FAS) test of Corynebacterium pseudodiphtheriticum. Foci of intense fluorescence corresponded to areas of bacterial adhesion observed under phase-contrast. Micrographs of control strains Escherichia coli E2348/69 (FAS-positive) and E. coli DH5- $\alpha$ (FAS-negative) were not shown. Magnification: 1,000X.

significant $(p<0.001)$ increase in the number of viable intracellular bacteria of the HHC 1507 strain.

The inhibition of tyrosine kinases did not influence the adherence of HTR 1503 and only partially reduced the internalisation of the ATCC 10700 and HTR1503 strains. In contrast to the ATCC 10700 strain, the data suggest that the $\mathrm{HHC} 1507$ strain has an invasion process that involves actin polymerisation, but is largely independent of phosphotyrosine signalling.

Although the adherence and invasion of C. pseudodiphtheriticum involved actin polymerisation via a phosphotyrosine-signalling cascade, the data also suggest that some strains may be able to trigger actin polymerisation in HEp-2 cells independent of phosphotyrosine signalling. The data also suggest that microfilament-independent mechanisms are triggered during the adherence, entry and intracellular survival of some C. pseudodiphtheriticum strains in cultured human respiratory epithelial cells.

\section{DISCUSSION}

The behaviour of a microorganism within epithelial cells provides some insight into its overall pathogenic strategy. Bacterial adherence to mucosal and epithelial cell structures is important not only for microbial persistence in the airways, but also for its systemic dissemination (Riise et al. 2000). Moreover, the internalisation of bacteria by epithelial cells indicates that such species have developed specialised mechanisms that co-opt normal host cell functions and stimulate their own uptake and adaptation to the intracellular environment (Meyer et al. 1997). Infectious organisms are frequently introduced into the cell by endocytosis. Cytoplasmic vacuolisation and degradation suggest the death of infected cells, which could provide a route for the dissemination of microorganisms to distal sites, where foci of metastatic infection could be established (Henics \& Wheatley 1999). Previous studies have shown that diphtheria bacilli can enter epithelial cells through an intimate adherence to the cell membranes, as well as the presence of the bacteria inside vacuoles. Here, we showed that during the invasion of HEp-2 cells, numerous C. pseudodiphtheriticum bacteria are present within a single membrane-bound vacuole, concomitant with epithelial cell detachment. These mechanisms may be relevant for in vivo infections, allowing C. pseudodiphtheriticum to breach the epithelial cell barrier and enter deeper tissues.

In this study, C. pseudodiphtheriticum strains associated with human infection showed variations in their abilities to replicate in the extracellular environment and survive in the presence of HEp-2 cells. Our data also suggest that C. pseudodiphtheriticum not only multiplies at and remains on the surface of the host, but also may use its attachment to epithelial cells as an essential step to reach to deeper tissues or to other sites.

During infection, many pathogenic bacteria modulate the actin cytoskeleton of eukaryotic host cells to facilitate various infectious processes, such as the attachment to or invasion of epithelial cells. The much-studied enteropathogenic bacteria primarily usurp host cell microfilaments for entry (Chu \& Lu 2005). Entry into non-phagocytic cells involves a triggering of host signal transduction mechanisms to induce rearrangements of the host cytoskeleton, thereby facilitating bacterial cell uptake. Activation of the tyrosine kinase activity is a common feature in the signal transduction pathways that lead to the internalisation of invasive pathogens (Finlay et al. 1991, Tan et al. 1998).

In the invasion process of C. pseudodiphtheriticum, the binding of the bacterium triggers a signal in the epithelial cell that causes the re-organisation of the cytoskeleton components that surround the organism and provide the force necessary for bacterial uptake. However, C. pseudodiphtheriticum strains showed varying abilities to trigger host signal transduction mechanisms to induce such rearrangements of the host cytoskeleton during their invasion processes. Cytoskeletal rearrangement appeared to be partially triggered by activation of tyrosine kinases. Moreover, some strains of C. pseudodiphtheriticum may generate microfilament-independent pathways for bacterial uptake, as previously observed among other human pathogens (Meyer et al. 1997).

The adhesion to and intracellular persistence within HEp-2 cells were high in the piliated C. pseudodiphtheriticum ATCC 10700 strain. Unlike C. diphtheriae (MattosGuaraldi \& Formiga 1991), the C. pseudodiphtheriticum strains evaluated in this study were unable to agglutinate human erythrocytes. Therefore, the pilins of the C. pseudodiphtheriticum ATCC 10700 type strain were unable to function as erythrocyte agglutinins in sheep (Yanagawa \& Honda 1976) and humans. The observed differences in the ability of these strains to adhere, enter and survive within host cells suggest a qualitative and/ or quantitative diversity in the expression of the bacterial components that function as adhesin(s) and/or invasin(s).

In several studies, opportunistic and true pathogens have been classified based on their adherence patterns to tissue culture cells. The AA pattern of adhesion was recognised in Klebsiella pneumoniae strains that are associated with neonatal colitis in a nosocomial environment (Livrelli et al. 1996). For diarrhoeagenic Es- 
Associated (\%)
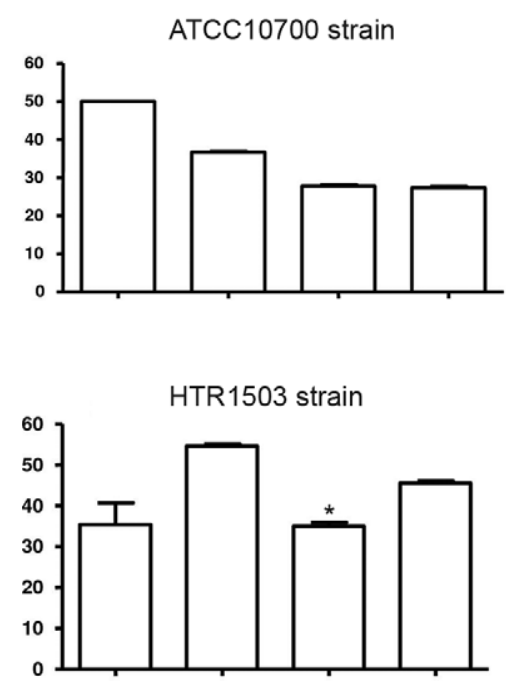

HHC1507 strain

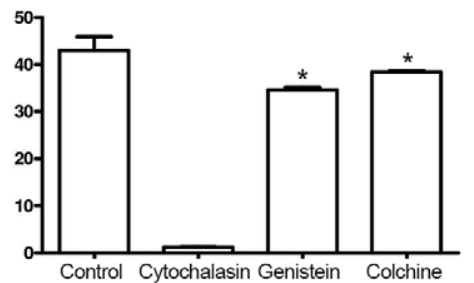

Internalised (\%)
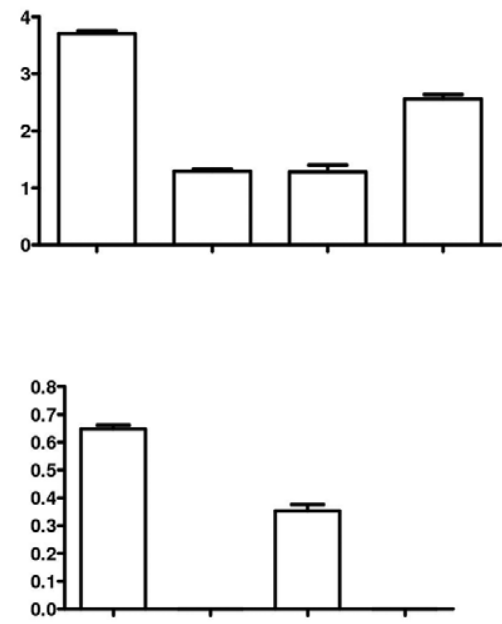

Fig. 3: effect of pre-treatment of human epithelial (HEp-2) cells with cytochalasin E, genistein and colchicine inhibition assays on adherence and entry of Corynebacterium pseudodiphtheriticum ATCC 10700, HTR1503 and HC1507 strains at 3 h post-infection. Each experiment was carried out in triplicate and repeated three times. Asterisk means $\mathrm{p}>0.05$.

cherichia coli, the association of adhesion patterns with different clinical syndromes has been well established (Nataro \& Kaper 1998). Recently, the AA properties of cultured epithelial cells were associated with the invasiveness and intracellular survival of enteroaggregative E. coli (EAEC) (Pereira et al. 2008) and C. diphtheriae (Hirata Jr et al. 2008) strains. All of the C. pseudodiphtheriticum strains tested were different from diphtheria bacilli and showed an AA-like pattern, regardless of the origin of the isolate. Similarly to EAEC, two C. pseudodiphtheriticum clinical isolates (ATCC10700/exudative pharyngitis and HTR1503/pneumonia) exhibited AAlike adhesive properties associated with invasiveness and intracellular persistence. The AA-like HHC1507/ bacteraemia strain was unable to persist in the intracellular compartment; viable bacteria were observed only in the supernatants. These data suggest differences in the virulence mechanisms of the various C. pseudodiphtheriticum strains.

Extracellular pathogens, such as uropathogenic $E$. coli (Mulvey et al. 2001) and Helicobacter pylori (Necchi et al. 2007), have been shown to transiently colonise the intracellular environment of the mucosal epithelia as a strategy for long-term persistence. Similarly, the ability of bacteria to survive within host cells may serve to intensify the pathogenicity of C. pseudodiphtheriticum. The utilisation of the intracellular space by C. pseudodiphtheriticum could be a means of survival under adverse extracellular conditions. The microorganisms tested were differentially able to enter and persist for long periods within epithelial cells from the human larynx. Investigations are just beginning to uncover the processes used by $C$. pseudodiphtheriticum to invade epithelial cells and breach the blood barrier. It is already clear that the processes used by this "opportunistic" bacterium mimic those used by a group of well-known invasive human pathogens. Our results suggest that epithelial cells may play a role in the dissemination of some C. pseudodiphtheriticum strains throughout the respiratory tract and other sites in the human body.

\section{ACKNOWLEDGEMENTS}

We are grateful to Noemia Rodrigues Gonçalves Alves and Maria Angélica Pereira da Silva, for technical assistance.

\section{REFERENCES}

Ahmed K, Kawakami K, Watanabe K, Mitsushima H, Nagatake T, Matsumoto K 1995. Corynebacterium pseudodiphtheriticum: a respiratory tract pathogen. Clin Infect Dis 20: 41-46.

Almuzara MN, De Mier C, Rodríguez CR, Famiglietti AM, Vay CA 2006. Evaluation of API Coryne System, version 2.0, for diph- 
theroid gram-positive rods identification with clinical relevance. Rev Argent Microbiol 38: 197-201.

Bittar F, Cassagne C, Bosdure E, Stremler N, Dubus JC, Sarles J, Reynaud-Gaubert M, Raoult D, Rolain JM 2010. Outbreak of Corynebacterium pseudodiphtheriticum infection in cystic fibrosis patients, France. Emerg Infect Dis 16: 1231-1236.

Burke GJ, Malouf MA, Glanville AR 1997. Opportunistic lung infection with Corynebacterium pseudodiphtheriticum after lung and heart transplantation. Med J Aust 166: 362-364.

Camello TCF, Souza MC, Martins CA, Damasco PV, Marques EA, Pimenta FP, Pereira GA, Hirata Jr R, Mattos-Guaraldi AL 2009. Corynebacterium pseudodiphtheriticum isolated from relevant clinical sites of infection: a human pathogen overlooked in emerging countries. Lett Appl Microbiol 48: 458-464.

Cantarelli VV, Brodt TC, Secchi C, Inamine E, Pereira FS 2008. Cutaneous infection caused by Corynebacterium pseudodiphtheriticum: a microbiological report. Rev Inst Med Trop Sao Paulo 50: 51-52.

Chiner E, Arriero JM, Signes-Costa J, Marco J, Corral J, Gomez-Esparrago A, Ortiz TV, Martin C 1999. Corynebacterium pseudodiphtheriticum pneumonia in an immunocompetent patient. Monaldi Arch Chest Dis 54: 325-327.

Chu WH, Lu CP 2005. Role of microfilaments and microtubules in the invasion of EPC cells by Aeromonas hydrophila. $J$ Vet Med B 52: $180-182$.

Chudnicka A, Szmygin-Milanowska K, Kieszko R, Milanowski J, Koziol-Montewka M 2003. The role of opportunistic species of Corynebacterium pseudodiphtheriticum in the pathogenesis of CAP (community acquired pneumonia). Ann Univ Mariae Curie Sklodowska Med 58: 142-148.

Colt HG, Morris JF, Marston BJ, Sewell DL 1991. Necrotizing tracheitis caused by Corynebacterium pseudodiphtheriticum: unique case and review. Rev Infect Dis 13: 73-76.

Craig TJ, Maguire FE, Wallace MR 1991. Tracheobronchitis due to Corynebacterium pseudodiphtheriticum. South Med J 84: 504506.

Das BB, Schnell P, Mendez H 2003. Corynebacterium pseudodiphtheriticum bacteremia in an immunocompetent adolescent: a case report an review of literature. Eastern J Med 8: 18-19.

Döpfer D, Nederbragt H, Almeida RA, Gaastra W 2001. Studies about the mechanism of internalization by mammary epithelial cells of Escherichia coli isolated from persistent bovine mastitis. Vet Microbiol 80: 285-296.

Finlay BB, Ruschkowsk S, Dedhar S 1991. Cytoskeletal rearrangements accompanying Salmonella entry into epithelial cells. J Cell Sci 99: 283-296.

Funke G, Bernard AK 2007. Coryneform Gram-positive rods. In PR Murray, EJ Baron, JH Jorgensen, ML Landry, MA Pfaller (eds.), Manual of clinical microbiology, ASM Press, Washington DC, p. 485-514

Henics T, Wheatley DN 1999. Cytoplasmic vacuolation, adaptation and cell death: a view on new perspectives and features. Biol Cell 91: 485-498.

Hirata Jr R, Napoleão F, Monteiro-Leal LH, Andrade AF, Nagao PE, Formiga LC, Fonseca LS, Mattos-Guaraldi AL 2002. Intracellular viability of toxigenic Corynebacterium diphtheriae strains in HEp-2 cells. FEMS Microbiol Lett 215: 115-119.

Hirata Jr R, Pereira GA, Filardy AA, Gomes DL, Damasco PV, Rosa AC, Nagao PE, Pimenta FP, Mattos-Guaraldi AL 2008. Potential pathogenic role of aggregative-adhering Corynebacterium diphtheriae of different clonal groups in endocarditis. Braz J Med Biol Res 41: 986-991.
Hirata Jr R, Souza SM, Rocha-de-Souza CM, Andrade AF, MonteiroLeal LH, Formiga LCD, Mattos-Guaraldi AL 2004. Patterns of adherence to HEp-2 cells and actin polymerization by toxigenic Corynebacterium diphtheriae strains. Microb Pathog 36: 125-130.

Izurieta HS, Strebel PM, Youngblood T, Hollis DG, Popovic T 1997. Exudative pharyngitis possibly due to Corynebacterium pseudodiphtheriticum, a new challenge in the differential diagnosis of diphtheria. Emerg Infect Dis 3: 65-68.

Kang MS, Gazdzinski P, Kleven SH 2002. Virulence of recent isolates of Mycoplasma synoviae in Turkeys. Avian Diseases 46: 102-110.

Kemp M, Holtz K, Andresen K, Christensen JJ 2005. Demonstration by PCR and DNA sequencing of Corynebacterium pseudodiphtheriticum as a cause of joint infection and isolation of the same organism from a surface swab specimen from the patient. $J$ Med Microbiol 54: 689-691.

LaRocco M, Robinson C, Robinson A 1987. Corynebacterium pseudodiphtheriticum associated with suppurative lymphadenitis. Eur J Clin Microbiol 6: 79.

Li A, Lal S 2000. Corynebacterium pseudodiphtheriticum keratitis and conjunctivitis: a case report. Clin Exp Ophthalmol 28: 60-61.

Livrelli V, De Champs C, Di Martino P, Darfeuille-Michaud A, Forestier C, Joly B 1996. Adhesive properties and antibiotic resistance of Klebsiella, Enterobacter and Serratia clinical isolates involved in nosocomial infections. J Clin Microbiol 34: 1963-1969.

Martaresche C, Fournier PE, Jacomo V, Gainnier M, Boussuge A, Drancourt M 1999. A case of Corynebacterium pseudodiphtheriticum nosocomial pneumonia. Emerg Infect Dis 5: 722-723.

Martins CAS, Faria LMD, Souza MC, Camello TCF, Velasco E, Hirata Jr R, Thuler LCS, Mattos-Guaraldi AL 2009. Microbiological and host features associated with corynebacteriosis in cancer patients: a five-year study. Mem Inst Oswaldo Cruz 104: 905-913.

Mattos-Guaraldi AL, Formiga LC 1991. Relationship of biotype and source to the hemagglutination and adhesive properties of $\mathrm{Co}$ rynebacterium diphtheriae. Braz J Med Biol Res 24: 399-406.

Meyer DH, Mintz KP, Fives-Taylor PM 1997. Models of invasion of enteric and periodontal pathogens into epithelial cells: a comparative analysis. Crit Rev Oral Biol Med 8: 389-409.

Moreira LO, Andrade AF, Vale MD, Souza SM, Hirata Jr R, Asad LM, Asad NR, Monteiro-Leal LH, Previato JO, Mattos-Guaraldi AL 2003. Effects of iron limitation on adherence and cell surface carbohydrates of Corynebacterium diphtheriae strains. Appl Environ Microbiol 69: 5907-5913.

Morinaga Y, Yanagihara K, Yamada K, Nakamura S, Izumikawa K, Seki M, Kakeya H, Yamamoto Y, Inoue Y, Kamihira S, Kohno S 2010. Two cases of Corynebacterium pseudodiphtheriticum respiratory tract infection. Kansenshogaku Zasshi 84: 65-68.

Morris A, Guild I 1991. Endocarditis due to Corynebacterium pseudodiphtheriticum: five case reports, review and antibiotic susceptibilities of nine strains. Rev Infect Dis 13: 887-892.

Mulvey MA, Schilling JD, Hultgren SJ 2001. Establishment of a persistent Escherichia coli reservoir during the acute phase of a bladder infection. Infect Immun 69: 4572-4579.

Nataro JP, Kaper JB 1998. Diarrheagenic Escherichia coli. Clin Microbiol Rev 11: 142-201.

Nathan AW, Turner DR, Aubrey C, Cameron JS, Williams DG, Ogg CS, Bewick M 1982. Corynebacterium hofmannii infection after renal transplantation. Clin Nephrol 17: 315-318.

Necchi V, Candusso ME, Tava F, Lunetti O, Ventura U, Fiocca R 2007. Intracellular, intercellular and stromal invasion of gastric mucosa, preneoplasic lesions and cancer by Helicobacter pylori. Gastroenterology 132: 1009-1023. 
Odeh R, Quinn JP 2000. Problem pulmonary pathogens: Pseudomonas aeruginosa. Semin Respir Crit Care Med 21: 331-339.

Olender A, Niemcewicz M 2010. Macrolide, lincosamide and streptogramin B-constitutive-type resistance in Corynebacterium pseudodiphtheriticum isolated from upper respiratory tract specimens. Microb Drug Resist 16: 119-122.

Pereira ACM, Britto-Filho JD, Carvalho JJ, Luna MG, Rosa ACP 2008. Escherichia coli enteroaggregative (EAEC) strains enter and survive within cultured intestinal epithelial cells. Microb Pathog 45: 310-314.

Riise GC, Qvarfordt I, Larsson S, Eliasson V, Andersson BA 2000. Inhibitory effect of $\mathrm{N}$-acetylcysteine on adherence of Streptococcus pneumoniae and Haemophilus influenzae to human oropharyngeal epithelial cells in vitro. Respiration 67: 552-558.

Roig P, Lopez MM, Arriero JM, Cuadrado JM, Martin C 1993. Corynebacterium pseudodiphtheriticum pneumonia in a patient diagnosed with HIV infection. An Med Interna 10: 499-500.
Roux V, Drancourt M, Stein A, Riegel P, Raoult D, La Scola B 2004. Corynebacterium species isolated from bone and joint infections identified by $16 \mathrm{~S}$ rRNA gene sequence analysis. J Clin Microbiol 42: 2231-2233.

Tan E, Low KW, Wong WSF, Leung Y 1998. Internalization of Aeromonas hydrophila by fish epithelial cells can be inhibited with tyrosine kinase inhibitor. Microbiology 144: 299-307.

Voiriot P, Charlin B, Marcoux JA, Guirgis H 1986. Subacute rhinosinusitis due to Corynebacterium pseudodiphtheriticum. CMAJ 134: 1034-1035.

von Graevenitz A, Punter-Streit V, Riegel P, Funke G 1998. Coryneform bacteria in throat cultures of healthy individuals. $J$ Clin Microbiol 36: 2087-2088.

Yanagawa R, Honda E 1976. Presence of pili in species of human and animal parasites and pathogens of the genus Corynebacterium. Infect Immun 13: 1293-1295. 